\title{
Free Will in the Summa Halensis
}

\begin{abstract}
Although the doctrine of free will was analyzed in different ways over the middle ages, there was broad agreement on two points, namely, that free will can only choose the good, and that it is a matter of both reason which determines what to do and the will that chooses it. Following the lead of Alexander of Hales, the Summa Halensis breaks from this longstanding tradition by describing free will as capable of choosing either good or evil, reinterpreting the words of major authorities like Augustine, Anselm, and Bernard of Clairvaux to support its opinion. According to the Summa, the only way to obtain merit or demerit is if both options are available. In a further development, the Summa follows Philip the Chancellor in arguing that free will, while entailing both reason and will, is more a matter of the will which chooses what to do, thus laying the foundation for the further development of voluntarism in the Franciscan intellectual tradition.
\end{abstract}

The concept or doctrine of free will (liberum arbitrium) represents an area of intensive early scholastic interest. ${ }^{1}$ While Augustine and Anselm's writings by the title De libero arbitrio were long known in the Middle Ages, more recent writings by John of Damascus, Bernard of Clairvaux, and Abelard, among others, stimulated new discussion and debate on the topic in this period. This chapter will show that the Summa Halensis takes a decisive new stance on the nature of free will, locating it more in the will than in reason, and defining it as capable of both good and evil rather than simply the good.

In these respects, the Summa's source of inspiration was Alexander of Hales, whose evident interest in the subject can be noted in his fairly extensive writings on the topic. The voluntarism he endorses, along with his definition of free will, we now know, would become defining features of the Franciscan school, not least in the work of John Duns Scotus. Here, consequently, the Halensian sources of later Franciscan thought are highlighted for the first time. As important as those sources are, I wish to show in this chapter that the Summa's account emerges as part of a conversation amongst predecessors and contemporaries, whose theories in some respects lay the groundwork for - though none goes so far as - the Summa itself.

The demonstration of this point in the present chapter will take the following form. I will first recount briefly the doctrine of free will advocated by Augustine, for whom free choice was a matter of reason and will's orientation to the good.

1 I am grateful to Riccardo Saccenti and Marcia Colish for comments on an earlier version of this paper. 
This view, we will see, was elaborated further by Anselm. John of Damascus added new terms and arguments to the discussion, which factored into key aspects of 12thcentury thought on the subject, which will then be treated briefly. The result will be to place on full display the constellation of sources and concepts that was at Alexander of Hales' disposal and that he was to some extent constrained to reconcile with his own opinions. A recounting of his theory of free choice as well as that of his main collaborator John of La Rochelle and the Summa will reveal that the latter depends upon the former, even while taking the 'irrefragible doctor's' position to new heights.

\section{Augustine}

There are many different interpretations of Augustine on free will, and there are some who would say he changed his mind on the subject over the course of his career. ${ }^{2}$ By contrast, Eleonore Stump observes that Augustine himself states in his Retractationes that his earlier thought in this topic was simply underdeveloped by comparison to his later views and is ultimately consistent with them. ${ }^{3}$ The views presented in his early work are very clearly outlined in the De libero arbitrio, one of the texts that was most well known and most cited by the Summists and their contemporaries. ${ }^{4}$ There, Augustine states that free will is given for the purpose of acting rightly; in other words, its purview does not include sin and evil. ${ }^{5}$ While he does acknowledge in a later work, De correptione et gratia, that humans are free to do good or evil after the fall, this claim is heavily qualified. ${ }^{6}$ For choices to sin are in fact 'free of justice but enslaved to sin."

This enslavement comes from confusing greater goods - ultimately, God - with lesser goods which are perceived as sources of happiness and fulfilment, something Augustine elsewhere describes in terms of concupiscence. The finite and fleeting, or changeable nature of goods other than God entails that pursuing them as matters of supreme importance for our happiness inevitably leads to the frustration of our de-

2 For example, Eugene TeSelle, 'Background: Augustine and the Pelagian Controversy,' in Grace after Grace, eds. Alexander Y. Hwang et al. (Washington, DC: Catholic University of America Press, 2014), pp. 1-13; John M. Rist, 'Augustine on Free Will and Predestination,' Journal of Theological Studies 20:2 (1969), p. 420, in pp. $420-47$.

3 Augustine, Retractions I.9; Eleonore Stump, 'Augustine on Free Will,' in The Cambridge Companion to Augustine (Cambridge: Cambridge University Press, 2014), p. 167 in pp. 166-86.

4 This work was finished before 395 according to Peter King; see Augustine: On the Free Choice of the Will, On Grace and Free Choice, and Other Writings, ed. Peter King (Cambridge: Cambridge University Press, 2010), p. xvii. It was followed by On Grace and Free Choice (426-27), On Reprimand and Grace (426-27), and On the Gift of Perseverance (428-29), works which were written primarily in relation to Pelagian controversy.

5 Augustine, De libero arbitrio 2.1.

6 Augustine, De correptione et gratia 12.32 (trans. King, p. 213); cf. 2.3 (trans. King, p. 186).

7 Augustine, De correptione et gratia 14.42 (trans. King, p. 222). 
sires. ${ }^{8}$ If we seek those goods as a matter of priority, in other words, we will be slaves to the pursuit of things we cannot always possess and will therefore never be happy. ${ }^{9}$ As Augustine is quick to stress, the objects of our desires themselves are not good or evil - only the use we make of them and the level of significance we attribute to them. ${ }^{10}$ That is why it is so important to attribute absolute significance to God alone: not because other goods are insignificant or devalued in Augustine's thought, but because we can only perceive their significance accurately and avoid enslavement to desires for them when we keep them in proper perspective. ${ }^{11}$

The success or failure to do just this, that is, to exercise free will, is precisely the realm of our moral responsibility in Augustine's paradigm. Admittedly, Augustine does say in his later works that we require God's grace for all the good that we do, in opposition to Pelagius who supposedly affirmed the possibility of achieving perfection without God's aid. ${ }^{12}$ Apart from the ongoing support of grace, Augustine insists, a person would simply revert to evil and sin. Contrary to what is often supposed in certain interpretations of Augustine, however, this does not imply that the human being is 'totally depraved' and defunct with regard to any good act. What it suggests, by contrast, is that God is the one who gives the ability to do good in the first place and restores that ability following its loss to sin. On this account, God is not the one performing good deeds on a person's behalf. Rather, he is the one and indeed the only one who can impart the power to act rightly in the first place.

\section{Anselm}

Anselm's account of free will in the De libero arbitrio - the text that was most wellknown to the Summists and their contemporaries - broadly follows the early Augustine at least in stating in no uncertain terms that the power of sinning is not a matter of free will. ${ }^{13}$ This is because sin enslaves us to desires for things that are not in our

8 Augustine, De libero arbitrio 2.19: sin involves turning to a lesser good.

9 Augustine, De libero arbitrio 1.11, 3.1: on slavery to sin.

10 Augustine, De libero arbitrio 1.16.

11 Augustine, De libero arbitrio 1.13.

12 Augustine, De gratia et libero arbitrio 5.12 (trans. King, p. 151).

13 As Mary Beth Ingham shows in her contribution to this volume, later Franciscans preferred some of Anselm's later works on free will, which Marcia Colish takes as an attack on the later, anti-Pelagian views of Augustine. See Marcia Colish, 'Free Will and Grace: Method and Model in Anselm's De concordia,' in Anselm of Canterbury: Nature, Order and the Divine, eds. Ian Logan and Giles G. E. Gasper, Anselm Studies and Texts (Leiden: Brill, 2021).

Anselm, De libero arbitrio 1. See the excellent account of Augustine and Anselm on free will in Riccardo Saccenti, Conservare la retta volontà: L'atto morale nelle dottrine di Filippo il Cancelliere e Ugo di Saint-Cher (1225-1235) (Bologna: Società editrice il Mulino, 2013), pp. 37-45. See also Odon Lottin, Psychologie et morale aux XIIe et XIIIe siècles, vol. 1 (Gembloux: J. Duculot, 1957), pp. 12-14: Anselm on free will. 
best interests and limits our freedom accordingly. ${ }^{14}$ On this basis, Anselm concludes that free will strictly speaking can only will what is good. As Anselm puts it, in language which had been hinted at but not employed to the same extent by Augustine, free will can only will to preserve the rectitude, justice, or righteousness of the will, for its own sake. ${ }^{15}$ To do precisely this is what Anselm following Augustine again affirms that human beings fittingly 'owe' to God. After all, the purpose for which they were made was to honor him by preserving the justice he instilled in them. ${ }^{16}$

That is not to suggest that humans are mere functionaries of the divine will; for doing what God wants us to do is in our own interests. Indeed, there is nothing about being a slave to sin that is consistent with human happiness and flourishing. As Augustine had affirmed, so Anselm posits that willing what God wants us to will, which is to will to treat him as the supreme good and regard all other goods as second to him, helps us put other goods in proper perspective so that desires for mundane things do not become inordinate and enslaving. In summary, the will to preserve the just and proper order of our will, first to God, and then to other things, is what truly liberates the will.

\section{John of Damascus}

The more recent authority, John of Damascus, whose De fide orthodoxa was translated in the 12th century, played a significant role in early Franciscan accounts of free will. From Damascus, early Franciscans adopt the idea that 'everything that is generable is changeable. ${ }^{17}$ As the very notion of generation involves a change, the implication is that created beings are changeable (vertibilis) by nature. In the case of human beings, that entails that they can will to do or not to do any given thing ( $\mathrm{fa}$ cere et non facere). In other words, they can voluntarily desire one thing but not another. ${ }^{18}$ As we will see, Alexander of Hales stretched the idea that free will entails

14 Anselm, De libero arbitrio 3 and 10.

15 Anselm, De libero arbitrio 13; cf. Augustine De Trinitate 14.15. Robert Pouchet, La 'rectitudo' chez Saint Anselme: Un itinéraire augustinien de l'Âme à Dieu (Paris: Études Augustiniennes, 1964); K. Trego, L'essence de la liberté: La refondation de l'éthique dans l'œuvre de s. Anselme de Cantorbéry, (Paris: Vrin, 2010).

16 Anselm, De libero arbitrio 3.15: 'Since no one overcomes the laws of the Almighty Creator, it is not permitted for the soul not to repay its debt. Now the soul repays it either by using well what it received, or by losing what it was unwilling to use well. Thus if the soul does not repay it by doing justice, it will repay it by suffering unhappiness, since in each case the word "debt" applies. We could put the point like this: "If the soul does not repay its debt by doing what it ought, it will repay its debt by suffering what it ought."'

17 John of Damascus, De fide orthodoxa: Versions of Burgundio and Cerbanus, ed. Eligius M. Buytaert (St Bonaventure: Franciscan Institute, 1955) c. 41, p. 152: 'Omne enim generabile et vertibile est.' See pp. 152-54 more generally on free will.

18 John of Damascus, De fide orthodoxa c. 40, p. 150. 
wanting 'this and not that' so far as to suggest that it allows for willing 'opposites', that is, good or evil. ${ }^{19}$

This perspective on the will represents a rather extreme take on the position of John of Damascus. ${ }^{20}$ As Michael Frede writes, 'looking at John of Damascus' account shows us that he does not construe choice as inherently a choice between two options, the good and the evil. ${ }^{21}$ As noted above, the Damascene's much simpler point, which is the product of his complex reception of Aristotle, the Stoics, and the Greek church fathers, is that the human will is not fixed to one object or another. $^{22}$ Different people desire different things, presumably in accordance with different abilities, interests and so on. Moreover, their desires and preferences can change. To observe this is a far cry from saying that evil is a legitimate object of free will.

\section{2th-Century Developments}

In addition to Augustine, Anselm, and Damascus, the 13th-century canon of authorities on free will expanded to include Bernard of Clairvaux, who wrote his account of 'grace and free will' around $1128 .^{23}$ There, he argued, among other things, that free will consists in consent which is not subject to any constraint or necessity. ${ }^{24}$ This consent is ultimately to God and thus to the good which is the source of all freedom. Although free will can do evil since its definition is not to be compelled to one thing or another, sin diminishes freedom which is more ordered or genuine in doing good than evil. ${ }^{25}$

In this connection, Bernard formulated a distinction between a three-fold freedom, namely, from necessity, from sin, and from misery, which became a fixture of medieval discussions of this topic, not least because it was included in Lombard's

19 Alexander of Hales, 'De libero arbitrio,' in Magestri Alexandri de Hales Quaestiones disputatae 'Antequam esset frater', vol. 1 (Quaracchi, Florentiae: Collegii S. Bonaventurae, 1960), q. XXXIII, p. 566.

20 Denise Ryan, 'An Examination of a Thirteenth-Century Treatise on the Mind-Body Dichotomy: Jean de La Rochelle on the Soul and its Powers' (PhD Thesis, National University of Ireland, Maynooth, 2010), p. 173.

21 Michael Frede, 'John of Damascus on Human Action, the Will, and Human Freedom,' in Byzantine Philosophy and its Ancient Sources, ed. Katerina Ierodiakonou (Oxford: Clarendon Press, 2002), pp. 63-95.

22 René A. Gauthier, 'Maxime le Confesseur et la psychologie de l'act humain,' Recherches de théologie ancienne et médiévale 21 (1954), pp. 51-100.

23 Bernard of Clairvaux, On Grace and Free Choice, ed. Daniel O’Donovan, intro. Bernard McGinn (Kalamazoo: Cistercian Publications, 1997).

24 Odon Lottin, Psychologie et morale, vol. 1, pp. 19-20.

25 Bernard of Clairvaux, The Treatise of St Bernard, Abbat of Clairvaux, Concerning Grace and Free Will, trans. Watkin Wynn Williams (New York: MacMillan, 1920), c. 4, p. 18. 
Sentences. ${ }^{26}$ The first freedom is a gift of nature, the second of grace, and the third of glory. In his De sacramentis fidei (1135-40), Hugh of St Victor also espoused the basic idea of free will as not being subject to any compulsion. ${ }^{27}$ So construed, freedom could be attributed not only to humans, but also to angels and God; in this period, as Mary Beth Ingham shows in her chapter for this volume, it remained a priority for scholars to find a definition that applied across the board.

Another key moment in the history of free will theory came with Peter Abelard, who introduced the definition of Boethius, or 'the philosophers' in his Introductio ad theologiam around 1138. This involved the idea of free will as 'voluntate iudicium', or a 'free judgment concerning the will' whereby we decide whether or not we will follow an inclination of the will. ${ }^{28}$ As Lottin notes, the deliberation in question is free, because it is exempt from any necessity. Thus, Abelard upholds the growing consensus that free will is the power to achieve what reason decides without any force or compulsion. That is not to say that free will entails freedom to sin, for sin diminishes freedom. The kind of freedom Abelard has in mind is of a different sort, and it pertains to the power to choose between different good alternatives.

A further advance which Lottin identifies in the 12th-century history of free will concerns the anonymous Summa Sententiarum, which has sometimes been attributed to Hugh of St Victor, but which Lottin assigns to Othon of Lucca, and which has more recently been traced to the school of Gilbert of Poitiers. ${ }^{29}$ This is the text that would formulate the definition of free will as the ability or 'facultas' of reason and will to choose the good, if the grace of God assists, and to choose evil, if grace ceases. ${ }^{30} \mathrm{Al}-$ though the author supports this idea with citations from Bernard, Peter Lombard would later associate it with Augustine. ${ }^{31}$

26 Bernard of Clairvaux, Concerning Grace and Free Will, c. 3, pp. 14-17: three kinds of grace; pp. 18-24: freedom from necessity, sin, and misery. The distinction that would become famous later on between posse non pecarre and non posse peccare is also found in chapter 7. See also Peter Lombard, Libri sententiarum. Magistri Petri Lombardi Parisiensis episcopi Sententiae in IV libris distinctae, 2 vols, 3rd ed. (Grottaferrata, Rome: Collegii S. Bonaventurae Ad Claras Aquas, 1971-81), bk. 2, d. 25, c. 8, p. 160.

27 Odon Lottin, Psychologie et morale, vol. 1, p. 22: Hugh of St Victor.

28 Odon Lottin, Psychologie et morale, vol. 1, p. 22: Petri Abaelardi Introductio ad theologiam, in Petri Abaelardi Opera II, ed. V. Cousin (Paris: A. Durand, 1859), p. 139; cf. PL 178:1110a. This was also quoted in the Sentences bk. 2, d. 25 c. 1, n. 2, p. 153.

29 L. Catalani, I Porretani. Una scuola di pensiero tra alto e basso Medioevo (Turnhout: Brepols, 2008). See also Marcia Colish, 'Otto of Lucca: Author of the Summa sententiarum?' in Discovery and Distinction in the Early Middle Ages: Studies in Honor of John J. Contreni, eds. Cullen J. Chandler and Steven A. Sofferahn (Kalamazoo: Medieval Institute Publications, 2013), pp. 57-70.

30 Odon Lottin, Psychologie et morale, vol. 1, p. 25.

31 Odon Lottin, Psychologie et morale, vol. 1, p. 28. See also Lombard, Sentences bk. 2, d. 24, c. 3, p. 142, trans. Giulio Silano, in The Sentences, Book 2: On Creation (Toronto: Pontificial Institute of Medieval Studies, 2008), p. 109: 'Free choice, however, is a faculty of reason and will, by which the good is chosen with the assistance of grace, or evil without its assistance. And it is called "free" in regard to the will, which may turn itself to either of them; but "choice" in regard to reason, whose faculty or 
The Lombard's work thus gave rise inadvertently to the subsequent debate on whether free will consists mainly in reason or in the will or even some other faculty that perhaps contains or exceeds those two. ${ }^{32}$ While Lombard continued to maintain the idea also found in the Summa sententiarum that free will is essentially the power to choose between different alternatives, he and his followers still did not count evil as a legitimate one of those options. This is why God can be said to have free choice in the truest sense of the term. ${ }^{33}$ For Lombard, free choice is unequivocally freer when one is not able to $\sin ^{34}$

The situation changed with Gandolph of Bologna, who around 1160-70 argued that free will involves a choice between good and evil, although Lottin notes that it is difficult to identify the sources of inspiration for this rather unconventional view. ${ }^{35}$ Simon of Tournai, a follower of the school of Gilbert of Poitiers, further elaborated a case for the idea that there are two different kinds of free will, namely, to do good, and to do evil. ${ }^{36}$ In some respects, he argued, the freedom to do evil is greater than that to do good, because we need grace to avoid evil. Nevertheless, the natural inclination of reason untainted by sin, and its true and proper end, is to choose the good. ${ }^{37}$

In the school of Peter Lombard, Praepositinus of Cremona pushes much further the idea of free will as consisting primarily in reason rather than the faculty of both reason and will, as Lombard supposed..$^{38}$ On his account, reason plays the role of discerning between good and evil; it chooses the good and detests evil. The will simply executes the orders of reason regarding our moral or immoral activities. As we move into the early 13th century, John Blund takes the traditional line on the nature of free will. ${ }^{39}$ He sees free will as entailing both reason and will, where reason knows what is good and the will chooses it, thus 'preserving righteousness' and rejecting its opposite.

power it is, and to which it also belongs to discern between good and evil.' See also Sentences bk. 2, d. 24, c. 1 (140), trans. Giulio Silano, quoting Augustine’s De corruptione et gratia 11.32: 'God gave a good will to man, indeed he made him upright in it; he gave him the help without which he could not remain steadfast in that will, if he so willed, and through which he could, but he left it to man's choice to do this.'

32 Odon Lottin, Psychologie et morale, vol. 1, p. 29.

33 Sentences bk. 2, d. 25, c. 1, p. 153.

34 Sentences bk. 2, d. 24, c. 4, p. 156.

35 Odon Lottin, Psychologie et morale, vol. 1, p. 38.

36 Odon Lottin, Psychologie et morale, vol. 1, p. 41.

37 When this fails to happen, Simon claims, it is not therefore because reason actually is able to command evil acts but rather because it allows them to be performed, inevitably at the impetus of lower impulses. Although reason is indirectly responsible for evil, because it fails to fulfil its duty to curb sin, its only proper object remains, as ever, the good.

38 Odon Lottin, Psychologie et morale, vol. 1, p. 50.

39 John Blund, Treatise on the Soul, eds. D.A. Callus and R.W. Hunt, trans. Michael W. Dunne (London: British Academy, 2012), pp. 213-21. 
Although he is not mentioned by name, Anselm is clearly at the background here, as is Augustine, whose spurious definition of free will is quoted, albeit from the Sentences, as 'a faculty of reason and understanding by which, with the help of grace, the good is chosen, and by which, when grace ceases, evil is chosen. ${ }^{, 40} \mathrm{Au}$ gustine's own wording of this sentiment states that 'free choice must be acknowledged as the ability we have to do good and to do evil. ${ }^{41}$ Blund's indebtedness to Augustine becomes evident in his emphatic rejection of the notion that it is possible for free will to sin or pursue what is evil. As he stresses, this would involve slavery to one's desires, which has nothing to do with the exercise of a free power. ${ }^{42}$

William of Auxerre's Summa aurea offers one of the first in-depth treatises on free will in the period post-Lombard. However, the author proves resistant to departing from the traditional Augustinian line in his account of free will. ${ }^{43}$ Like Blund, he states Augustine's view as represented by Lombard: ${ }^{44}$ 'free will is the operation of will and reason by which good is chosen with the assistance of grace and evil when grace is lacking. ${ }^{45}$ In this connection, he expounds on Praepositinus' argument that free will consists primarily in reason - which he now perhaps under Aristotle's influence refers to specifically as 'practical reason'. He makes his case by distinguishing between two levels of judgment, the first of which discriminates between two options and the second of which elects one over the other. ${ }^{46}$ The second is the proper act of free will and the locus of merit.

For William, there is as Augustine said a place for the will proper as well as reason within free will - which can therefore be said to include both - but only insofar as the will is part of reason's second act. ${ }^{47}$ In addition to this, William insists that free

40 John Blund, Treatise on the Soul, p. 223.

41 Augustine, De correptione et gratia 1: 'Liberum itaque arbitrium et ad malum et ad bonum faciendum confitendum est nos habere.'

42 John Blund, Treatise on the Soul, p. 217.

43 William of Auxerre, Summa aurea, bk. 2, tome 1, Spicilegium Bonaventurianum 17, ed. Jean Ribaillier (Paris: Grottaferrata, 1982), pp. 274-309; see also bk. 2, tome 2, Spicilegium Bonaventurianum 18 (Paris: Grottaferrata, 1982), pp. 470 -510. See a fuller account of William's doctrine of free will in Riccardo Saccenti, Conservare la retta volontà, pp. 116-21.

44 William of Auxerre, Summa aurea, bk. 2, tome 1, p. 276. Peter Lombard, Sentences bk. 1, d. 24, c. 3, p. 453.

45 William of Auxerre, Summa aurea, bk. 2, tome 1, p. 276: 'Liberum arbitrium est facultas voluntatis et rationis qua bonum eligitur, gratia assistente; malum vero gratia desistente.' Augustine, De correptione et gratia 11.31, trans. King, p. 212: 'Free choice is sufficient for evil, but hardly for good, unless it is assisted by the omnipotent Good One.'

46 Odon Lottin, Psychologie et morale, vol. 1, p. 67; William of Auxerre, Summa aurea, bk. 2, tome 1, p. 276.

47 See an excellent discussion by Tobias Hoffman which focusses on questions of the relationship between necessity and freedom in Auxerre, the Chancellor, Hugh of St Cher and others, 'Freedom without Choice: Medieval Theories of the Essence of Freedom,' in The Cambridge Companion to Medieval Ethics, ed. Thomas Williams (Cambridge: Cambridge University Press, 2019), pp. 196-97, in pp. 194-216. 
will is more related to the good than evil, citing Augustine's De civitate Dei 12.7, where he states that 'evil is not an efficient but a deficient cause. ${ }^{48}$ Later on, he reiterates this view, and its association with Augustine, quoting the latter's De libero arbitrio 2.19.53, which states that 'the ability to sin is not an ability' strictly speaking, for precisely the reason Blund already mentioned, namely, that it limits the scope of free will rather than facilitating it. ${ }^{49}$

In summary, for William, free will is the power of choosing to do what synderesis dictates. ${ }^{50}$ As has been noted, synderesis or right reason, also described by some as natural law, was a term derived from the writings of Jerome and first given an extended treatment by Auxerre, after which it became a standard topic in the schools. ${ }^{51}$ The proper motion of free will is to choose to do or not to do one thing over another - but its options must always be consistent with what synderesis would require. ${ }^{52}$

As Saccenti observes, Philip the Chancellor represents a new phase in work on free will. This is not only because his account of free will takes up more space in his section on human nature than all other topics combined: around 75 pages of an approximately 150-page text..$^{53}$ Nor is it simply because he introduces the thelesis/boulesis distinction as well as the distinction between cognitive and motive powers which are found in John of Damascus and would later be more or less adopted in the same way by John of La Rochelle. ${ }^{54}$ Although Philip is indebted to the main sources - Augustine, Anselm, and Bernard ${ }^{55}$ - that also feature in the Summa Halensis, he breaks from his predecessors to argue that free will is identical with the will rather than reason. In his opinion, it is the will rather than reason that possesses the power to act or not to act and thus to acquire or lose merit. ${ }^{56}$

48 William of Auxerre, Summa aurea, bk. 2, tome 2, p. 275: 'Mali non est causa efficiens sed deficiens.'

49 William of Auxerre, Summa aurea, bk. 2, tome 2, p. 489.

50 William of Auxerre, Summa aurea, bk. 2, tome 2, p. 283.

51 Philippi Cancellarii Parisiensis Summa de bono, 2 vols, ed. Nikolaus Wicki (Bern: Francke, 1985), pp. 129-30: Philip the Chancellor created the formal tract on the topic and most subsequent thinkers simply answered questions in the order he listed them, including Hales, Odo Rigaldus, Albert the Great, and Thomas Aquinas, according to Michael Bertram Crow, 'Fresh Lineaments of the Natural Law,' in The Changing Profile of the Natural Law (The Hague: Martinus Nijhoff, 1977), pp. 111-35. 52 William of Auxerre, Summa aurea, bk. 2, tome 2, p. 278.

53 Summa de bono, pp. 155-231: as mentioned previously, the discussion of the motive powers and free will take up the greater proportion of his section on human nature, which ends on p. 297. 54 Summa de bono, p. 160: provides a summary or John's division between cognitive and motive powers; p. 161: treats the distinction between thelesis and boulesis. On the use of Damascus by the Chancellor in treating these concepts, see Riccardo Saccenti, Conservare la retta volontà, pp. 91-101. 55 Summa de bono, pp. 165-66, citing the definitions of Augustine, Anselm and Bernard on free will. 56 Odon Lottin, Psychologie et morale, vol. 1, pp. 73-74. Summa de bono, p. 173: 'Libertas autem principaliter residet apud illam potentiam in quantum est voluntas' ['Liberty principally resides in the power of the will']; pp. 175-76: free will is mainly in doing what one wills rather than what reason dictates, because this is how we acquire merit and demerit; cf. Riccardo Saccenti, Conservare la retta volontà, p. 124. 
That is not to say that for Philip, reason has no role to play in free will. Rather it is a question of which power assumes primacy in this context. According to Philip, free choice is ultimately the power to do what one wills, that is, the power of self-determination. As Lottin explains, however, this power for Philip does not include that of doing evil, which diminishes freedom. ${ }^{57}$ Although Philip in that sense adheres to Anselm's definition of free will, he acknowledges that it is not adequate to explaining how those who do evil can have free will. ${ }^{58}$ To address this problem, he argues that the power of preserving the rectitude of which Anselm speaks remains even in the person who fails to use it. ${ }^{59}$

By contrast to Philip, Hugh of St Cher takes a more 'intellectualist' line on free will. He acknowledges that some see free will as reason, others as will, others as a composite of these two, adding that others, presumably Godfrey of Poitiers, regard it as something over and above reason and will. ${ }^{60}$ Nevertheless, he refuses to accept that there is any faculty in the person that is superior to reason, which has the power to determine how to act, a determination that is executed by free will. In this regard, as Lottin notes, he is visibly influenced firstly by William of Auxerre, whose work, we have learned, he often reiterates while sometimes making additions or changes to William's solutions. ${ }^{61}$

Elsewhere, Hugh acknowledges that free will can be defined as flexible to do whatever it wants or as flexible between good and evil. In his view, however, free will is not flexible between good and evil but only to do what it wants within the parameters of the good. ${ }^{62}$ Further details of the accounts given by both Philip and Hugh are superbly outlined by Riccardo Saccenti in his book on the subject. ${ }^{63}$ Although Roland of Cremona was Hugh's teacher, we know that he was probably more influenced by his student than the other way around, since he only wrote his own Summa after Hugh's major Sentences Commentary was completed. For his

57 Odon Lottin, Psychologie et morale, vol. 1, pp. 79-80. Riccardo Saccenti, Conservare la retta volontà, p. 135. Summa de bono, p. 162: on the flexibility of free will between good and evil.

58 Summa de bono, pp. 184-85: 'Similiter dicit esse in libertate arbitrii quod nichil prohibet libertatem arbitrii esse quantum ad hoc quod est potestas conservandi rectitudinem non existente rectitudine, quamdiu ratio est in nobis, qua eam valeamus cognoscere et voluntas qua illam tenere possumus.'

59 Riccardo Saccenti, Conservare la retta volontà, pp. 137-38.

60 The Quaestiones of Stephen Langton identify free will with the rational faculty, holding that this embraces reason and will.

61 Odon Lottin, Psychologie et morale, vol. 1, pp. 96-103.

62 See the edition at Riccardo Saccenti, Conservare la retta volontà, pp. $230-31$.

63 Riccardo Saccenti, Conservare la retta volontà, pp. 142-51: on free will in Hugh of St Cher. See also Magdalena Bieniak, 'Contents of Hugh of St Cher's Commentary on the Sentences, Books I-II,' Przeglad Tomistyczny 19 (2013), p. 76 in pp. 9-90. See also her 'The Sentences Commentary of Hugh of St Cher,' in Medieval Commentaries on the Sentences of Peter Lombard, vol. 2, ed. Philipp Rosemann (Leiden: Brill, 2002), pp. 139-40 in pp.111-47. On p. 135 she notes that Hugh was the first to speak of the absolute/ordained power distinction in a theological context. 
part, however, he offers a somewhat unique solution, which seemingly seeks to accommodate in a qualified way the idea that free will can in fact choose evil.

To this end, Roland invokes the famous Augustinian distinction between higher and lower reason, which was codified by Lombard, arguing that while lower reason which is linked to the body is capable of choosing good and evil, higher reason is independent of it and always retains its preference for the good. ${ }^{64}$ At this level, consequently, free will only involves the power to choose whatever one wills, that is, not to be determined to any one object but to be able to discriminate and choose amongst various good options. ${ }^{65}$ As this suggests, Roland follows Hugh or at least William of Auxerre in emphasizing that free will - at least higher by contrast to lower free will - is basically reason. ${ }^{66}$

\section{John of La Rochelle}

Before moving on to Alexander of Hales, it is worth pausing to reflect on John of La Rochelle's treatment of free will. Although John is influenced by Philip the Chancellor in his account of many matters, this is a case where he does not take Philip's radical line of referring free choice to the will. According to Lottin, he instead identifies free choice (liberum arbitrium) with the rational faculty, more specifically, the practical intellect, which is comprised of reason (ratio) and will (voluntas) and their operation, which is that of liberum arbitrium itself. For John, these three represent one and the same faculty that only differs according to its acts. ${ }^{67}$ While reason discerns or refrains from seeking knowledge (agnoscit) of what is to be done, the will, previously described as boulesis, desires the good to be done, and liberum arbitrium chooses the desired good. ${ }^{68}$

As Augustine put it, free choice is one power in its root but three in its branches. This point was consistent with Augustine's broader view, presented in De Trinitate,

\footnotetext{
64 Odon Lottin, Psychologie et morale, vol. 1, pp. 103-8: on Roland of Cremona and free will. Summae Magistri Rolandi Cremonensis, O.P., Liber Secundus, eds. Aloysio Cortesi and Humberto Midali (Bergamo: Umberto Midali, 2016), p. 144: citing Augustine's De Trinitate 12.7.12, Roland distinguishes between higher and lower reason and on p. 233, he states that inferior reason can move between good and evil, though higher reason is ordered towards the good.

65 Summae Magistri Rolandi Cremonensis, O.P., Liber Secundus, pp. 237-38: there is flexibility to choose between different objects of desire but not between good and evil (liberi arbitrii est potestas sed flexibilitas ad id quod vult habens liberum arbitrium).

66 Summae Magistri Rolandi Cremonensis, O.P., Liber Secundus, p. 234: free will is reason for Roland. 67 Odon Lottin, Psychologie et morale, vol. 1, p. 128: Rochelle says free will is the rational faculty, under the influence of Hugh.

68 John of La Rochelle, Tractatus de divisione multiplici potentiarum animae. Texte critique avec introduction, notes et tables (Tractatus), ed. Pierre Michaud-Quantin (Paris: Vrin, 1964), p. 98: 'Sicut enim habemus vim intellectiuam ordinatam ad verum, sic habemus vim intellectiuam motiuam ordinatam ad bonum. Notandum ergo quod est vis motiua ut natura et est vis motiua ut ratio.'
} 
that the mind, its knowledge and its will represent an image of the Trinity; to give one primacy over the other would be to imply inequality within the Trinity and thus heresy. ${ }^{69}$ In this connection, John notes that free choice can be understood in two ways, distinctly or indistinctly. In a distinct or specific sense, free choice is the final arbiter of the work of will and reason. In this case, each of the three faculties have their own proper operation: reason discerns, the will desires, and free will chooses. In an indistinct sense, however, Damascus says that free will can be said to apply to any aspect of the process of free willing and thus to the work of reason and will individually, as when we say that one thinks freely, wills freely, and chooses freely. ${ }^{70}$

Although John allows with his contemporaries that free will is the power to act without determination or external pressures, this does not amount for him to a power to choose between good and evil. As John notes, 'free will is not called liberum because it is flexible between good and evil but because it is able to do or not to do something, as it consults and is instigated by synderesis, or as it is suggested by sensuality. ${ }^{71}$ This power is what sets human beings apart from animals, which operate under the force of instinct and are in that sense tied to their desires for material objects. Since volitions follow intelligible goals which are free from matter, they are undetermined and can be focussed on any good end or object whatever.

\section{Alexander of Hales}

As Lottin has aptly observed, Alexander of Hales has little in common with his Franciscan contemporary John of La Rochelle as regards free will. ${ }^{72}$ This is a topic Alexander covers in both his Glossa and his disputed questions, and the level of interest he had in the subject is apparent from the amount of space he devotes to it in both places. ${ }^{73}$ For instance, questions about the relationship between sin, grace, and free will consume around half of the second volume of his Gloss. ${ }^{74}$ The three volumes of disputed questions that date from before Alexander became a friar are highly selective in the topics they cover; the questions overwhelmingly deal with issues in moral and sacramental theology and the Trinity.

69 I am grateful to Marcia Colish for making this point to me.

70 De fide orthodoxa 36.12.

71 Tractatus, p. 121: libero arbitrio.

72 Odon Lottin, Psychologie et morale, vol. 1, p. 134: Alexander of Hales has little in common with Rochelle on free will.

73 Magistri Alexandri de Hales Quaestiones disputatae 'Antequam esset frater' (Quaracchi: Collegii S Bonaventurae, 1960), tome 1, q. 33, m. 3, d. 3, p. 592 in pp. 566-608: Alexander says free will is the same as prohaeresis and contrasts it with synderesis which innately moves the will to the good. 74 Magistri Alexandri de Hales Glossa in quatuor libros Sententiarum Petri Lombardi (Quaracchi: Collegii S Bonaventurae, 1952), vol. 2, pp. 181-421; pp. 1-15, reason of creation; pp. 15-116, angels; pp. 116-45, the seven days of creation; pp. 145-81, the creation of Adam and Eve; pp. 181-421, sin, grace, and free will. 
Among these is Alexander's lengthy question 33 on free will and several appended questions, which witness to his preoccupation with the subject matter. Although much of the material from the Gloss is repeated in the disputed questions - most importantly question 33 - the account of the matter in that question is the most coherent and extensive one he left us, partly because the Gloss format constrained Alexander to follow Lombard's line of reasoning, more than his own. The overlaps between Alexander of Hales' question 33 on free will and the account of this topic in the Summa Halensis are countless and striking and make evident that his work is the source for the Summa's treatment of this topic more than John of La Rochelle's. ${ }^{75}$

Alexander's argument in this context proceeds as follows: every creature that comes into being moves from non-being. Thus, he says, as Damascus writes, everything generable is changeable. ${ }^{76}$ The ability to change can be simpliciter, but this is not possible for rational beings because they are immortal; that is to say, they cannot revert back into non-being. ${ }^{77}$ Thus, the ability of humans must involve change between the good in which they were made, on the one hand, and evil, on the other. On this basis, Alexander says that the rational creature must be changeable and therefore flexible between good and evil as regards free will. In sum, the creation of the human being from nothing is the reason for the ability to will opposites, namely, good and evil. ${ }^{78}$

To the objection that this is not possible because God is good, and humans are made in the image of God, Alexander observes that creatures are unlike God, because they are made from nothing and are therefore changeable and able by nature to turn away from the good in which they were made. ${ }^{79}$ In response to Anselm's claim that 'willing evil is a defect of liberty,' Alexander states that this is only the case when we think of graced human nature - and that, Alexander claims, is the state to which Anselm refers. ${ }^{80}$ In the case of the liberty of nature, humans are able to do good as much as what is not good, and the power of doing evil is not called servitude, because it is not simply a matter of being compelled by nature or instinct to do something, as is the case with animal.

Later on in the question, Alexander reinforces this point when he says that Anselm's definition only really applies insofar as free will is common to God, good an-

75 Alexander of Hales, Questiones disputatae 33, disp. 1, m. 1, pp. 566-608, quoting De fide orthodoxa II.27.

76 Alexander of Hales, Questiones disputatae 33, disp. 1, m. 1, contra 9, p. 569.

77 Alexander of Hales, Questiones disputatae 33, disp. 1, m. 1, contra 10, p. 569.

78 Alexander of Hales, Glossa, vol. 2, p. 209b.

79 Alexander of Hales, Questiones disputatae 33, disp. 1, m. 1, n. 16, p. 572; see also the Glossa, vol. 2, p. 209b, on the idea that humans are changeable between good and evil because they are not like God.

80 Alexander of Hales, Questiones disputatae 33, disp. 1, m. 1, n. 20, p. 573. 
gels, and graced human beings. ${ }^{81}$ This, Alexander believes, is how Lombard understands free will in his Sentences, namely, insofar as it is common to God and creatures and thus not related to evil. ${ }^{82}$ When it comes to rational beings in their own right, however, free will pertains to both good and evil. ${ }^{83}$ In short, it involves consent to either one and entails the power to do effectively whatever one wants, whether good or evil. ${ }^{84}$

On another note, Alexander takes the view, in relation to the contemporary debate on the matter, that free will is a separate faculty which contains both reason and will. This tri-partite dimension is what renders free will an image of the Trinity where the Son represents knowledge or reason, the Spirit, will, and the Father an ultimate decision or operation - that therefore involves both reason, will, and their cooperation (facultas). ${ }^{85}$ After marshalling a series of proof texts from some of the usual suspects - Bernard, Damascus, and Augustine, however - Alexander draws the conclusion that even though a preliminary cognitive act is needed to weigh what one should do, free will is ultimately a matter of willing to do it and thus in essence pertains more to the will than reason. ${ }^{86}$ In fact, Alexander goes so far as to say, following Philip the Chancellor, that it really is just a matter of the will. ${ }^{87}$

To justify this in relation to Augustine, he notes like John that one can speak of free will distinctly or indistinctly. To speak of free will indistinctly is to speak of reason, will, and their operation as Augustine does. ${ }^{88}$ But to speak of it distinctly is only to speak of the will. ${ }^{89}$ For this very reason, Alexander further argues that sin is primarily in the will. ${ }^{90}$ In other words, it is not a matter of knowing what is right or wrong, which is instilled in us by synderesis or the natural law, which gives us an innate orientation to the good. Rather, it is a matter of refusing to do what is good. This is quite a contrast to someone like Augustine and later Anselm and Aquinas, who held that sin was both a matter of reason and will. In the account of these thinkers, reason starts to think of its supreme good as consisting in something other

81 Alexander of Hales, Questiones disputatae 33, disp. 2, m. 1, Respondeo 33, p. 576.

82 Alexander of Hales, Questiones disputatae 33, disp. 3, Respondeo, p. 587, citing Lombard's Sentences, bk. 2, d. 25.

83 Alexander of Hales, Questiones disputatae 33, disp. 3, Respondeo, p. 587: 'Secundo modo libera voluntas in bono et in malo.'

84 Alexander of Hales, Questiones disputatae 33, disp. 3, Respondeo 60, p. 587: 'Et sic est libertas quia potest in hoc vel in illud consentire.' See also p. 588, Ad 63: 'Liberum arbitrium potest facere quodlibet;' cf. Alexander of Hales, Questiones disputatae 33, disp. 1, m. 2, n. 24, p. 574.

85 Alexander of Hales, Questiones disputatae 33, disp. 2, m. 2, p. 581.

86 Alexander of Hales, Questiones disputatae 33, disp. 2, m. 1, n. 50, p. 583.

87 Alexander of Hales, Questiones disputatae 33, disp. 2, m. 1, n. 51, p. 584.

88 Alexander of Hales, Questiones disputatae 33, disp. 2, m. 1, n. 54, p. 584.

89 Alexander of Hales, Glossa, vol. 2, p. 212, 8a, 8c: 'Dicendum quod liberum arbitrium est primo ipsius voluntatis et secundum voluntatem est omnium actuum aliorum.' ['It is said that free will is first of the will and all other acts are according to the will.'] See also p. 226.

90 Alexander of Hales, Glossa, vol. 2, d. 39, n. 4, p. 378. 
than God - as this or that 'lesser good' - and therefore organizes life around obtaining that good, by virtue of a will to do so. ${ }^{91}$

The co-operation of reason and will in Augustine's account of free choice calls into question the legitimacy of the kind of voluntarist reading of his thought that was offered by early Franciscans. ${ }^{92}$ Although many modern scholars have taken that reading at face value, the early Franciscan texts we are examining here themselves provide evidence that Franciscans departed from Augustine's thinking on this matter in the very act of interpreting him. They illustrate how far someone like Alexander had to stretch Augustine's words in order to make a case to readers that the Bishop attributes primacy to the will.

By prioritizing goods other than God, Alexander suggests, the will can gradually obscure its knowledge of God and of the natural law, increasingly compromising its ability to will what is good. However, it cannot simply forget what it knows about him, for this would imply a deficiency in God and his ability constantly to make himself knowable to us through his image in us. While a bad will can make us ignorant of the good, consequently, Alexander concludes that the knowledge of it in synderesis can never be extinguished. For this reason, Alexander elaborates, merit and demerit consist primarily in the will..$^{93}$

Since synderesis is innate to all and cannot be depleted, in other words, one cannot accumulate merit on the basis of what one knows. Rather, one can only accumulate merit on the basis of what one decides to do with that knowledge, or what one wills. ${ }^{94}$ According to Alexander, the philosophers did not know of free will precisely because they did not know the principle of meriting by consenting to the divine will. ${ }^{95}$ Through the natural grace that all human beings possess (gratia gratis data), Alexander claims, human beings are able to resist venial though not mortal $\sin .{ }^{96}$ The latter can only be overcome or resisted with so-called sanctifying grace

91 As Anselm notes, this becomes a matter of slavery precisely because things other than God are finite and fleeting. To pursue them above all is else to put our happiness at the mercy of circumstances that are out of our control.

92 This is demonstrated by A. San Cristóbal Sebastián, Controversias acerca de la voluntad desde 1270-1300 (Madrid: Editorial y librería co., 1958), p. 111, pp. 118-28. On p. 98, Sebastián also shows that medieval writers discussed liberum arbitrium until 1270; after this time, they frequently spoke in terms voluntas libera - freedom of the will and more occasionally, liberum arbitrium.

93 Alexander of Hales, Questiones disputatae 33, disp. 3, m. 4, pp. 592-93; see also Alexander of Hales, Glossa, vol. 2, Respondeo 7, p. 211.

94 Alexander of Hales, Questiones disputatae 33, disp. 3, m. 4, p. 593: 'Dico ergo quod meritum penes voluntatem attenditur et penes liberum arbitrium, quoniam duo ad hoc exiguntur, scilicet separare appetendum a non appetendo, et hoc est liberi arbitrii; et adhaerere illi, et hoc voluntatis est; unde penes liberum arbitrium initiabitur, penes voluntatem consummabitur.' See also Alexander of Hales, Glossa, vol. 2, d. 25, p. 224.

95 Alexander of Hales, Questiones disputatae 33, disp. 3, m. 5, n. 77, p. 594.

96 Alexander of Hales, Questiones disputatae 33, disp. 5, m. 1, Respondeo 104, p. 601. 
(gratia gratum faciente), which works on those who are open to receiving it by faith, which is a movement of the will to conform to the will of God.

\section{The Summa Halensis}

The Summa Halensis clearly follows the lead of Alexander of Hales on the nature of free will. ${ }^{97}$ This becomes exceptionally clear in a section on 'whether free will is indifferent to good and evil. ${ }^{98}$ Here, the Summa quotes Damascus saying that 'the rational creature is changeable so far as choice is concerned. ${ }^{, 99}$ As we have seen, this principle was the basis for the Damascene's argument that free will entails the ability to choose between opposites, which he understands to entail a variety of good options. Thus, he writes that free will is the ability 'to be moved or not to be moved, to order to do or not to do, to desire or not to desire' any given thing. ${ }^{100}$ Taking a cue from Alexander, however, the Summa contends that the changeability of human nature presupposes 'the power to choose between opposites'101 of good and evil. On the basis of Damascus, consequently, the Summa draws a conclusion that Damascus did not, namely, that free will is indifferent to good or evil. ${ }^{\text {'102 }}$ That is to say, 'free will is that by which one is able to sin or do right. ${ }^{103}$ No author previous to or outside of the Franciscan tradition had dared to make such a claim without extensive qualifications.

In this regard, the Summa acknowledges that Anselm and Bernard denied that the power of sinning is part of free choice. ${ }^{104}$ The same objection is traced to Augustine's De libero arbitrio 2.1-2 which states that God gives human beings free will that it can be rightly used, not so that it can be used for wrongdoing. Additionally, the

97 This is well demonstrated in the following section: SH II, In4, Tr1, S2, Q3, T3, M1 (n. 389), pp. 466-67. A translation of this material has been prepared by Oleg Bychkov in The Summa Halensis: A Reader, trans. Lydia Schumacher and Oleg Bychkov (New York: Fordham University Press, forthcoming).

98 SH II, In4, Tr1, S2, Q3, T3, C3, Ar1 (n. 397), Circa primum sic obicitur a, p. 475.

99 SH II, In4, Tr1, S2, Q3, T3, C3, Ar1 (n. 397), Circa primum sic obicitur a, p. 475: 'Creatura rationalis vertibilis est secundum electionem,' quoting De fide orthodoxa II.27.

100 SH II, In4, Tr1, S2, Q3, Ti3, M3, C2 (n. 403), Ad 1, p. 480, citing De fide orthodoxa II.26: 'Liberi arbitrii est moveri vel non moveri, impetum facere et non facere, appetere et non appetere.'

101 SH II, In4, Tr1, S2, Q3, Ti3, M5, C2 (n. 411), Ad a, p. 487: 'Liberum enim arbitrium est potestas ad opposita.'

102 SH II, In4, Tr1, S2, Q3, T3, C3, Ar1 (n. 397), Circa primum sic obicitur a, p. 475: 'Creatura rationalis vertibilis est secundum electionem, ex hoc enim liberum arbitrium est, quod eligere potest vel recusare. Cum ergo eligere sit indifferenter inter utrumque, et recusare similiter, ergo liberum arbitrium indifferenter dicitur boni et mali.'

103 SH II, In4, Tr1, S2, Q3, Ti3, M3, C5 (n. 406), Ad 2, p. 483: 'Liberum arbitrium est quo homo potest peccare et recte agere.'

104 SH II, In4, Tr1, S2, Q3, T3, C3, Ar1 (n. 397), Contra 1, p. 475, citing Anselm's De libero arbitrio 1, Contra 2, citing Bernard's De grat. et lib. arbit. 9. 
Summist quotes De civitate Dei 14.11.1, which states that free will is free as it is not enslaved to $\sin .{ }^{105}$ In the response to the objection, the Summist states that free will can be considered in three ways. ${ }^{106}$ In the first way, it is considered insofar as it is not restricted (non cogitur), and in this sense, it is indifferent to good or evil; in another mode, free will is considered according to nature, which is assimilated to God and thus ordained to the good, and in this way, as Anselm says, the ability to do evil is not a part of freedom. ${ }^{107}$ The third mode considers free will in relation to the defect of nature which it has insofar as it is a creature, and according to the defect of the will which is proper to it, and in this way, it tends more to evil than to the good.

After saying that, however, the Summa denies that there is any fundamental difference between free will in the states of nature, grace, or glory. In all cases, it is a matter of having the option to serve either good or evil. The main difference between the pre-lapsarian state and the present one is simply that humans started out in the good, and were indeed designed by God to serve that end, even though they did not use the power they had to remain steadfast in it. The following argument, found in the 'contra' section, is indicative of what ends up being the Summa's position: 'just as humans could change their choice and remained flexible in the first state [of innocence], so [they can] in the states of sin and grace; but sharing the same ability namely, to change one's choice - amounts to sharing the same free choice; therefore, all three states share the same kind of free choice. ${ }^{108}$

On this basis, the Summa concludes that 'the servitude of sin is not compatible with the freedom of grace, but it is compatible with natural freedom. For this reason humans do possess free choice that stems from natural freedom in both states, i.e. of grace and sin. ${ }^{109}$ Perhaps conscious that its radical position was not so easy to reconcile with the leading authorities on free will, namely, Anselm, Augustine, and Bernard, the Summa proceeds to dedicate an entire section to the exposition of their opinions, which are also found already in Alexander of Hales' question 33, and to seek essentially to explain away the thrust of their perspectives in order to justify its own. ${ }^{110}$

105 SH II, In4, Tr1, S2, Q3, T3, C3, Ar1 (n. 397), Contra 4, p. 475, citing Augustine’s De civitiate Dei 14.11.1.

106 SH II, In4, Tr1, S2, Q3, T3, C3, Ar1 (n. 397), Respondeo, p. 476.

107 SH II, In4, Tr1, S2, Q3, T3, C3, Ar1 (n. 397), Respondeo, p. 476, citing De libero arbitrio 1 and 3: 'Posse facere malum non est pars libertatis.'

108 SH II, In4, Tr1, S2, Q3, T3, M3, C4 (n. 405), Respondeo, p. 482, trans. Oleg Bychkov.

109 SH II, In4, Tr1, S2, Q3, T3, M3, C4 (n. 405), Ad objecta 2, p. 482.

110 SH II, In4, Tr1, S2, Q3, T3, C2 (n. 392), p. 471. 


\section{Anselm, Augustine, and Bernard on Free Will}

The first definition of free will the Summa considers is that of Anselm in De libero arbitrio 13, which states that 'free choice is the power of preserving rectitude for its own sake.' ${ }^{111}$ On this account, the power of sinning lessens freedom and is no part of free will. The problem this poses for the Summa is that its definition entails that free choice involves options of preserving or deserting rectitude. ${ }^{112}$ To get around the problem, the Summa observes that the power of preserving rectitude can be understood in several ways, namely, on the part of the one who preserves rectitude, on the part of what is preserved, that is, 'the right thing to do', and on the part of the means through which it is preserved.

When all three of these factors are taken into account, there is no power of preserving rectitude without rectitude itself. However, when we consider the power to preserve only in terms of the nature of the one who has the power, the power of preserving rectitude can be said to exist even if there is no rectitude. This, the Summist surmises, is the view of Anselm and what he intends to convey with the analogy of vision he presents in his De libero arbitrio, which notes that the power of seeing remains in the agent even if there is no object of vision - as in the dark - and no actual vision is taking place.

Naturally, that was not the sense in which Anselm clearly intended his analogy to be interpreted in De libero arbitrio 7. His objective was only to suggest that free will is present even when we are not using it, as when we are asleep. Nevertheless, this same justification for effectively rejecting Anselm's position was given by Alexander of Hales in his question 33, namely, that the power of preserving rectitude remains even when the right thing is not done but evil is done instead. ${ }^{113}$ On this basis, the Summist concludes that Anselm believes that the power to preserve rectitude which is the definition of free will does not actually depend on acting rightly. In this way, he paves the way for the view that free will can also serve evil.

The next definition the Summist considers if that of Augustine, or at least Lombard's rendering of Augustine, as follows: 'free will is the operation of will and reason by which the good is chosen through the assistance of grace and evil resisted also by grace. ${ }^{114}$ As Anselm says, so the Summa allows that the power of sinning lessens freedom, and so the one who is able to act rightly and is not able not to do so is more free. ${ }^{115}$ In the response, he says that there is a three-fold liberty, name-

111 SH II, In4, Tr1, S2, Q3, T3, C3, Ar1, Pr1 (n. 393), Ad 1, p. 472: 'Liberum arbitrium est potestas servandi rectitudinem propter se.'

112 SH II, In4, Tr1, S2, Q3, T3, C3, Ar1, Pr1 (n. 393), Ad 2, p. 472.

113 Alexander of Hales, Questiones disputatae 33, disp. 2, m. 1, Respondeo 34, p. 577.

114 SH II, In4, Tr1, S2, Q3, T3, C3, Ar1, Pr2 (n. 394), Ad 1, p. 472: 'Liberum arbitrium est facultas rationis et voluntatis, qua bonum eligitur gratia assistente et malum eadem desistente.' See also Augustine, De corrept. et grat. 11.32 (PL 44:935); Peter Lombard, II Sent., d. 24, c. 3, p. 421.

115 Citing Anselm, De libero arbitrio 2.3. 
ly, of nature, grace and glory. The liberty of nature is from force or compulsion, the liberty of grace is from sin, and the liberty of glory is from misery.

According to the Summa, the idea that free will precludes sin does not pertain to the liberty of nature, for as Bernard says, 'as in the good, so in the bad, the will equally endures.' ${ }^{116}$ Rather, it concerns the liberty of guilt and misery. For guilt can be augmented and lessened as can misery, but this is not the case with nature, which is changeable. Thus, the power of choosing evil when grace is lacking is part of liberty, not insofar as it is enjoyed in common with God, but insofar as it pertains to creatures only. As in the case of Anselm above, so this justification for rejecting Augustine is reproduced virtually verbatim from Alexander of Hales' question 33. ${ }^{117}$

Finally, the Summa addresses the definition of Bernard of Clairvaux in his De libero arbitrio 2.4: 'free choice is consent on the basis of the freedom of the will that cannot be lost and the judgment of reason that cannot be changed. ${ }^{118}$ According to Bernard, this consent is a medium between the sense of the mind and the sense of the flesh. While the sense of the mind cannot pertain to evil, the sense of the flesh cannot pertain to anything good. When understood in terms the mind, consequently, Bernard says that 'no one would try to say that free will is a power or faculty that can alternate between good and evil. ${ }^{119}$ As the medium between the mind and the senses, however, consent is indifferent to good and evil. For it is capable of preferring what is good and ultimately God or of declining it. ${ }^{120}$ This again is a position largely repeated from Alexander of Hales. ${ }^{121}$

\section{Free Will: Will or Reason?}

As noted already, Alexander and the Summa Halensis take the position that free will is comprised of both reason and will and cannot be reduced to just one of them. As the Summa nicely puts it, free will 'is arbitrium according to reason and liberum according to will, ${ }^{122}$ although the operation of liberum arbitrium is seemingly something over and above reason and will which includes them. On this basis, Lottin ob-

116 Bernard of Clairvaux, De grat. et lib. arbit. 8.24.

117 Alexander of Hales, Questiones disputatae 33, disp. 2, m. 1, Respondeo 38, pp. 578-79.

118 SH II, In4, Tr1, S2, Q3, T3, C3, Ar1, Pr3 (n. 395), p. 473, citing Bernard of Clairvaux, De grat. et lib. arbit. 3.7 (PL 182:1005): 'Liberum arbitrium est consensus ob voluntatis inamissibilem libertatem et rationis indeclinabile iudicium.'

119 SH II, In4, Tr1, S2, Q3, T3, C3, Ar1, Pr3 (n. 395), Ad 1, p. 473, citing Bernard of Clairvaux, De grat. et lib. arbit. 10.35: 'Nemo putet ideo dictum liberum arbitrium quia inter bonum et malum potestate vel facultate versetur.'

120 SH II, In4, Tr1, S2, Q3, T3, C3, Ar2 (n. 396), Solutio, p. 474.

121 Alexander of Hales, Questiones disputatae 33, disp. 2, m. 1, Respondeo 39, p. 579; see also disp. 3, m. 1, n. 63, p. 588; n. 77, p. 594.

122 SH II, In4, Tr1, S2, Q3, T3, C3, Ar4 (n. 401), Respondeo 1, p. 478. 
serves that free will for them has two stages, namely, deliberation and choice. In its first stage, free will judges what to do according to the moral law; secondly, it chooses, and in this sense, it can become released from the law to do as it pleases. ${ }^{123}$

To defend its position, the Summa marshals quotations from both Bernard of Clairvaux and Augustine which argue for as well as against the idea that free will primarily concerns the will rather than reason. ${ }^{124}$ On the authority of Augustine, who says that nothing is in our control except the will, the Summa eventually concludes that free will is primarily a matter of the will. ${ }^{125}$ This is because the will is the one that ultimately exercises the power of free choice. The Summa responds to the objections to its position as follows:

Therefore, to those authoritative statements of the saints that seem to conclude that free choice
is the will, one must reply that the saints do not intend to say that free choice is essentially the
will, but that freedom mostly has to do with the will, and free choice is called will for this reason
alone. ${ }^{126}$

A closely related question to this one is whether merit and demerit are based on the will only or on the work of both reason and will. The Summa's solution to this problem clearly states that merit consists in a general sense in all aspects of free will, namely, reason, will, and their operation through the exercise of free choice. The involvement of all three renders free choice an image of the Trinity, where the Son represents reason, the Spirit, will, and the Father the ultimate arbiter of free choice. The fact that free will pertains more to the will than to anything else, however, suggests that merit is accumulated mostly through the will.

The reason the philosophers, and presumably Aristotle, did not know about free choice or discuss it explicitly, the Summist argues, is that they did not concern themselves with the principle of merit and demerit before God. They knew about the power of choosing opposites, though they did not speak of it in terms of liberum arbitrium. ${ }^{127}$ However, they did not know about the grace that makes free willing meritoriously possible.

With such words, the Summist introduces what would soon become one of the defining features of the Franciscan school: its voluntarism. As we have seen, all human beings on the early Franciscan view have an innate knowledge of the Highest Good that gives them equal access in principle to the knowledge of what is good to do and ultimately God. What determines whether that access is utilized is however the will to do so. According to the Summa, all human beings have in principle the

123 Odon Lottin, Psychologie et morale, vol. 1, pp. 140-49: the Summa Halensis on free will.

124 SH II, In4, Tr1, S2, Q3, T3, C3, Ar2 (n. 398), p. 476.

125 SH II, In4, Tr1, S2, Q3, T3, C3, Ar2 (n. 398), Ad a, p. 476, citing Augustine, De libero arbitrio 3.3.7, p. 476.

126 SH II, In4, Tr1, S2, Q3, T3, C3, Ar3 (n. 392), Ad objecta 1-5, p. 470.

127 SH II, In4, Tr1, S2, Q3, T3, C3, Ar4 (n. 401), Ad c, p. 478: 'Liberum arbitrium est potestas faciendi quodlibet aut potestas ad opposita.' 
complete freedom to choose without any compulsion between good and evil. It is for this very reason that the choices they make to prefer the good are so rightly credited to them as meritorious.

\section{A Metaphysics of Evil}

The early Franciscan view that evil can vacillate between good and evil was not an isolated position. A broader metaphysics of evil runs throughout the Summa Halensis, which derives mostly from Alexander of Hales. As Oleg Bychkov has shown, Alexander was the pioneer of a quite remarkable position that evil contributes to the beauty of the universe by throwing the good into greater relief. ${ }^{128} \mathrm{He}$ did this in sharp contrast to Peter Lombard before him, who insisted that God did not want evil to exist or to emerge, and to Albert the Great, who strongly opposed his position. $^{129}$

In addition to what Bychkov describes as the 'aesthetic value' of evil, early Franciscans regarded evil as essential to free choice, insofar as freedom and merit are only attained when there are two legitimate options to choose from: good and evil. As we have seen, evil only exists because human beings are created from nothing and can alternate for this reason between the good God intended for them, and its opposite, namely, evil. ${ }^{130}$ The reason God is not responsible for evil, on this showing, is that he is only the cause of the good in which he originally created humans, albeit with the power to will the opposite of the good, namely, evil, to their own merit or demerit. ${ }^{131}$

For obvious reasons, this position resulted in the attribution of some kind of substantiality to evil, against the grain of the previous Western tradition, which was dominated by the idea that evil is not strictly speaking 'something' but an absence of the good. This is certainly a view to which the Summa pays lip service, not least through quotations to the major proponents of the theory, including Augustine, Pseudo-Dionysius, Isidore of Seville, and Gregory the Great. ${ }^{132}$ All of these thinkers deny that evil is a substance and treat it as a privation of the good.

In a radical departure from the tradition, however, the Summa tries to create a space for a positive conception of evil by distinguishing between three different ways of defining a being, in terms of esse rationis, esse naturae, and esse moris. In

128 Oleg Bychkov, 'Decor ex praesentia mali: Aesthetic Explanations of Evil in Thirteenth-Century Franciscan Thought,' Recherches de Théologie et Philosophie médiévales 68:1 (2001), pp. 250-51 in pp. 245-69.

129 Oleg Bychkov, 'Aesthetic Explanations of Evil,' p. 265.

130 SH III, In1, Tr1, Q3, M1, C3 (n. 5), Respondeo, p. 11; cf. C5 (n. 7), Respondeo, p. 13: 'Liberum arbitrium est principium omnis mali culpabilis.' ['Free will is the beginning of all culpable evil.']

131 SH III, In1, Tr1, Q3, M2 (n. 8), Respondeo 1-2, p. 14.

132 SH III, In1, Tr1, Q1 (n. 1), Ad 1-10, p. 2. 
the first sense, something is an entity if there can be a correspondence between the thing and the mind. Here, evil is something because it deforms that in which it exists, namely, the human mind. ${ }^{133}$ As regards esse naturae, moreover, evil is something, by virtue of the fact that it is diffused in the world through evil acts which are in fact 'something'. 134

When talking about esse moris, the Summist admits that evil is not strictly speaking 'something', because esse in this sense refers to the order human beings have to God. Since evil persons lack this order, they do not possess esse moris. Although the human capacity or nature to serve the good and God remains despite these circumstances, it is reduced until they turn from sinful ways. ${ }^{135}$ What is remarkable about this way of putting things is that it attributes substantiality to evil in the very areas where previous generations of Christian thinkers in the West refused to do so.

For someone like Augustine, evil thoughts (esse rationis) and evil actions (esse naturae) lacked substance precisely because they lacked the qualities that God intended human thoughts and acts to possess: they exhibited a deficiency in the good that reduced their quality as beings. In the view of the Summist, however, the thoughts and actions in question remain thoughts and actions, the reality of which needs to be recognized if they are to be considered legitimate objects of free choice per the Summa's account of this topic above. The Summa allows that those who pursue evil contradict God's design and so lack being in the sense of esse moris. This, however, is a heavily qualified way of describing evil as privation.

While the Summa acknowledges that the sinful human person is not living as they should be, it still admits by virtue of the categories of esse rationis and esse naturae that the evil acts or intents of the sinful person are nonetheless 'something'. For all practical purposes, evil on this account is not a privation of the good but a positive reality which can be entertained by those who turn away from God. For this very reason, however, evil is something that God can incorporate into accomplishing the good, as Bychkov has shown. In summary, the very substantiality attributed to it by early Franciscans means that it is material that can be employed, whether by God or by good humans, to achieve his ends, at the impetus of the free will to do so.

133 SH III, In1, Tr1, Q1 (n. 1), Respondeo, p. 2: 'Est enim esse rationis, secundum quem modum quaecumque veritatem habent, id est adaequationem rei et intellectus dicuntur entia: secunduni hunc modum malitia est, cum deformat illud in quo est.'

134 SH III, In1, Tr1, Q1 (n. 1), Respondeo, p. 2: 'Est etiam esse naturae: et secundum hunc modum, ratione eius quod substernitur malitiae, dicitur malum esse aliquid, ut mala actio ratione actionis dicitur esse aliquid.'

135 SH III, In1, Tr1, Q1 (n. 1), Respondeo, p. 2: 'Est iterum esse moris, prout esse est quod ordinem retinet servatque naturam.' 